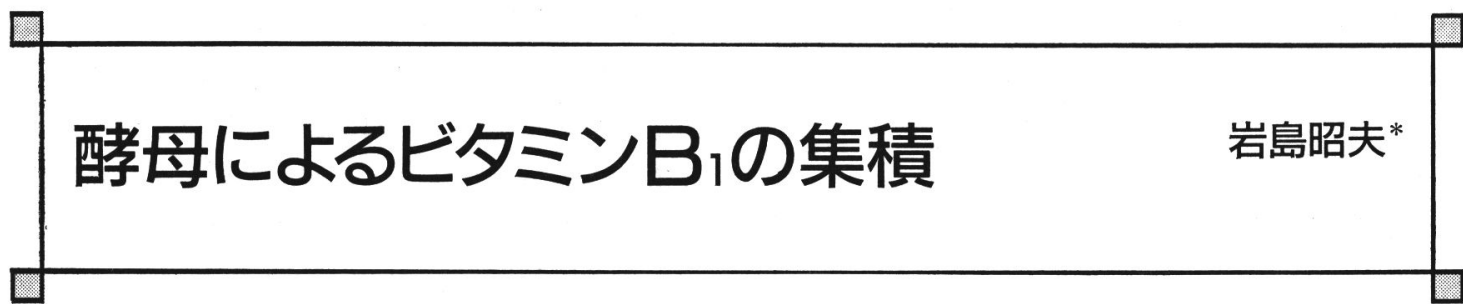

酵母には培地中のビタミン $\mathbf{B}_{1}$ をほとんど定量的に細胞内に集積する能力があることが古くから知られており， 我が国ではビタミン $\mathbf{B}_{1}$ の初めての単離にこの性質が利用された. このようなビタミン $\mathbf{B}_{1}$ の選択的な集積に は, 酵母細胞膜の輸送系が主役を演じ, さらにその働きが多彩な調節を受けることが明らかになってきた.

酵母は元来, ビタミン $B_{1}$ (チアミン) を生合成 することができる単細胞の真核生物であるが，酵 母細胞中のチアミン含有量は, その生合成能以上 に, 外部環境中に存在するチアミン量によって左 右される.これは酵母に外界のチアミンを取り込 んで細胞内に蓄積する能力が備わっていることに よるが, 酵母の菌種によっては, その量が乾燥重 量の $10 \%$ 近くにまで達することが知られてい る(1). このよらな酵母のチアミン集積能について は, すでに 1922 年に Eijkman ら (2)の報告があ り, 我が国でも高田 ${ }^{(3)}$ や大獄 ${ }^{(4)}$ (1933) の先駆的 研究がみられるが, 殊に後者は酵母のもつこの特 性を利用して，天然物抽出液よりチアミンを分離 濃縮し, その結晶化に成功している. その後, Suzuoki ${ }^{(5)}$ （1955） はパン酵母の細胞懸濁液を用 いて，チアミンの集積作用を定量的に検討し，チ アミンの取り込みがエネルギーを必要とする能動 輸送により起こることを初めて明らかにした。

一方, 酵母にはチアミンの生合成の直接の前駆 体であるヒドロキシメチルピリミジンと，ヒドロ キシェチルチアゾールを速やかに取り込んで，チ アミンに合成し蓄積する能力もあることが知られ ている(6). 酵母細胞内に取り込まれたこれらのチ アミン前駆体や，チアミンの代謝経路を図1に示 したが, 最終的にはチアミンの補酵素型であるチ アミンピロリン酸に変化して生理作用を発揮す る.

本稿では, 酵母によるチアミンの集積に直接関 与するチアミンとチアミン関連化合物の細胞膜輸

Transport and Accumulation of Vitamin $B_{1}$ in Yeasts

* Akio IWASHIMA, 京都府立医科大学生化学教室

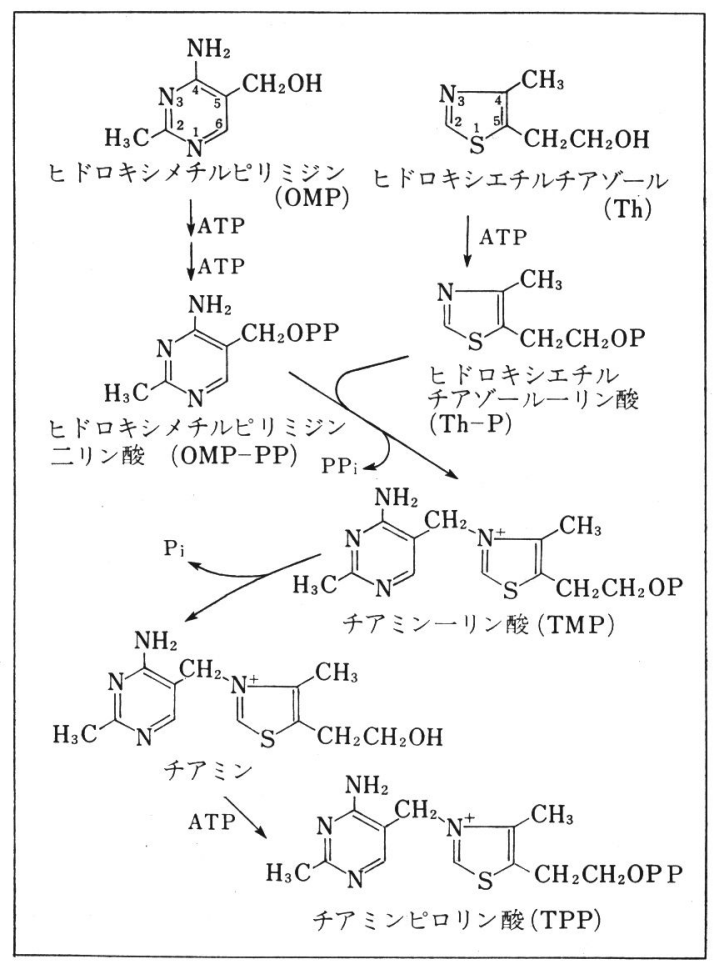

図 1 ・酵母におけるチアミンピロリン酸の生合成経路 ヒドロキシメチルピリミジン: 2-メチル-4-アミノー5-ヒドロキ シメチルピリミジン, ヒドロキシエチルチアゾール：4-エチル5 - $\beta$-ヒドロキシェチルチアゾール,

$-\mathrm{P}:-\stackrel{\mathrm{O}}{\mathrm{P}}-\mathrm{OH}$

送ととの調節について，筆者らの研究室で得られ た実験結果を中心に概説するとともに，チアミン の集積が酵母の増殖や代謝に与兄る影響より，そ の生理的意義についても考察を加えた.

\section{酵母のチアミン輸送系の性質}

パン酵母（Saccharomyces cerevisiae）をブドウ 


\section{表 1 酵母のチアミン輸送系の一般的性質}

\begin{tabular}{|c|c|}
\hline 温度依存性（至適温度） & あり $\left(37^{\circ} \mathrm{C}\right)$ \\
\hline $\mathrm{pH}$ 依存性（至適 $\mathrm{pH}$ ) & あり（pH 4.5〜5） \\
\hline エネルギー依存性 & あり \\
\hline チアミンとの親和性 & 高い $\left(K_{\mathrm{m}}=0.18 \mu \mathrm{M}\right)$ \\
\hline $\begin{array}{l}\text { 集䅣するチアミンの主要な形 } \\
\text { (細胞内外の濃度比) }\end{array}$ & $\begin{array}{l}\text { 遊離型チアミン } \\
(10,100)\end{array}$ \\
\hline $\begin{array}{l}\text { 輸送基質特異性 } \\
\text { (構造類似体にる阻害) }\end{array}$ & 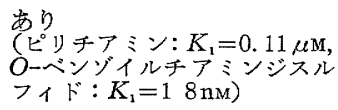 \\
\hline チアミンによる調節 & あり（抑制性） \\
\hline
\end{tabular}

糖を含むりン酸緩衝液に懸濁し， $37^{\circ} \mathrm{C}$ で予温後， ${ }^{14} \mathrm{C}$ で標識したチアミンを添加し，経時的に細胞 をニトロセルロース膜上に濾取して，取り込まれ た放射能を測定すると，チアミン輸送系によるチ アミンの取り込みを定量的に 調べることができ る. 酵母のチアミン輸送系の一般的性質 ${ }^{(7)}$ を表 1 に要約したが, 取り込みの反応の至適温度は $37^{\circ} \mathrm{C}$, 至適 $\mathrm{pH}$ は 4.5〜 5 で，チアミンに対する $K_{\mathrm{m}}$ 值は $0.18 \mu \mathrm{M}$ であり, 輸送系のチアミンに対 する親和性が高いことを示している.

また，最大取り込及時に括ける細胞内外の遊離 型チアミンの濃度比は注涪 10,000 で，この值は これまで報告された細菌や動物細胞のチアミン輸 送系や, 酵母の他の輸送系と比較して著しく大き いものである(8). このような酵母のチアミン集積 力には, 酵母の菌種による差異が認められるが, 一般に Saccharomyces 属の活性が強く，中には de novo のチアミン生合成量の約 3,000 倍も集 積するものがあり ${ }^{(9)}$, 同一の酵母でも対数増殖初 期の細胞がチアミンを最も活発に取り込むことが 知られている(10).

チアミンの取り达みのためのエネルギー源とし ては，嫌気，または好気条件ともにブドウ糖が最 もよく，好気条件下でェタノールをエネルギー源 とした場合は，ブドウ糖の約 $30 \%$ の活性を示 す.ブドウ糖添加による嫌気条件下での取り込み は, 解糖阻害椷であるモノョード酢酸やフッ化ナ トリウムにより，なたエタノールを用いての好気 条件下での取り达みは，呼吸阻害剤であるシアン 化カリウムにより著しく阻害され, 解糖, または 呼吸により生成するATPが取り达みのためのエ ネルギーとして必要であることがわかる(11)，さら
に, 酵母細胞膜の $\mathrm{H}^{+}$輸送性 ATPase を阻害す るジェチルスチルベステロールや, 本酵素により 細胞内外に形成される $\mathrm{H}^{+}$の濃度勾配を消失させ る2,4-ジニトロフェノールが, チアミンの取り込 みを強く阻害することより，酵母に和けるチアミ ンの細胞膜輸送は糖やアミノ酸の 輸送 ${ }^{(12)}$ で明ら かにされているよらに, $\mathrm{H}^{+}$-ATPase により生じ た $\mathrm{H}^{+}$の電気化学的ポテンシャルを利用する二次 性能動輸送により起こるものと考えられる.

次に，チアミンの細胞膜輸送のキャリアー（輸 送タンパク質）依存性については，本タンパク質 の活性が遺伝的に欠如しているためにチアミンの 輸送能を失ったと考えられる突然変異株（チアミ ン輸送欠損変異株）を分離することにより証明さ れている(13). すなわち，チアミン拮抗体の一つで あるピリチアミンは，チアミンをチアミンピロリ ン酸に転換するチアミンピロホスホキナーゼ (EC 2.7.6.2）を阻害することにより酵母の増殖を阻 害するが，ピリチアミンに対して 親株の 1,000 倍以上の耐性を獲得した一変異株 (PT-R 2) に は，ピリチアミンのみならずチアミンの酵母細胞 内への取り込及が皃とんど羿められず，このこと から酵母がチアミンとピリチアミンを共通の輸送 系により能動輸送すること, さらに本輸送系を構 成するキャリアー活性の欠如がピリチアミン耐性 の原因であることが明らかになった。

チアミン輸送系の基質特異性に関しては，チア ミンの各種構造類似体による阻害から検討されて いるが(10)，チアミンやピリチアミンのように完全 なピリミジン部と，これにメチレン結合した 4 級 アミンを共通構造にもつ化合物は, いずれも強い 拮抗阻害を示すのみならず，それら自体もチアミ ン輸送系により能動輸送される ${ }^{(13,14)}$. 一方, ピリ ミジン環の 2 位のメチル基や 4 位のアミノ基が修 飾されると阻害作用が低下し，殊に 4 位が水酸基 により置換されたオキシチアミンには阻害作用が ほとんど認められないことから，酵母のチアミン 輸送系はチアミンのピリミジン部に対して高い特 異性を示すと考学られる。このことは，チアミン のチアゾール部に相当するヒドロキシェチルチア ゾールや，その $N$-メチル誘導体には阻害作用が 
認められないのに対して，ピリミジン部を構成す るヒドロキシメチルピリミジンが単独で阻害作用 を示すことからも支持される，この他，酵母の場 合は易吸収性のチアミン誘導体として，ヒトの臨 床でも使用されている脂溶性のチアミン誘導体 （たとえば，O-ベンゾイルチアミンジスルフィド） による阻害が著しく(15)，このことはチアミンキャ リアーの細胞膜内に括汀る存在様式に, 膜の蹯水 性環境が密接に関わっている可能性を示唆してい るが，これと対照的に，極性の高いチアミンリン 酸エステルの阻害作用は弱く, 輸送系のこれらに 対する親和性がより低いことを示している.

酵母のチアミンキャリアーの化学的実体につい ては未だ明らかではないが，その機能に密接に関 与していると考えられるチアミン結合タンパク質 が，酵母の細胞膜に存在することが証明されてい $る^{(10,16)}$. この膜結合性チアミン結合タンパク質と チアミンの結合反応は， ${ }^{14} \mathrm{C}$ 標識チアミンを用い て平衡透析法により測定することができ，反応の 至適 $\mathrm{pH}$ ，チアミンに対する親和性，基質特異性 などの性質がチアミン輸送系の性質とよく一致す ることが見いだされている(8).さらに，前述のチ アミン輸送欠損株の細胞膜にはこの結合活性が注 とんど検出されないことから，膜結合性チアミン 結合タンパク質がチアミンの細胞膜輸送に直接関 与する機能成分であることが強く示唆されてい $ろ^{(10,16)}$. また，本タンパク質は，その生合成が糖 タンパク質の合成阻害剤であるッニカマイシンに より阻害され，同時に細胞のチアミン輸送能も低 下するので, 酵母細胞膜には糖タンパク質として 局在し，作用するものと考えられる(17).

筆者ら ${ }^{(18,19)}$ は, 最近この膜結合性チアミン結合 タンパク質を標識する目的で，光反応性を有する チアミンのアジドベンゾイル誘導体とそのジスル フィド化合物を数種類合成し, 酵母によるチアミ ンの取り达みに及ぼす影響を調べたところ，いず れも強い拮抗阻害作用を示し, さらに可視光線の 照射下で膜結合性チアミン結合タンパク質を失活 させることにより, チアミン輸送系を特異的に不 活性化させることが明らかになった．そこで，こ れらの誘導体の中から 4-アジド-2-ニトロベンゾ
イルチアミンを ${ }^{3} \mathrm{H}$ で標識し, 光照射下で酵母細 胞と反応させたのち，細胞膜タンパク質を SDS ゲル電気泳動で分画したところ，チアミンに特異 的な光親和標識が分子量 $6 \sim 8 \mathrm{~K}$ の画分に検出さ れた ${ }^{(20)}$.この標識タンパク質はチアミン輸送欠損 株の細胞膜からは証明されないので，膜結合性チ アミン結合タンパク質か，その構成成分である可 能性が高いが，その構造とチアミン輸送に和汀る 機能については，今後さらに明確にされねばなら ない.

\section{チアミン関連化合物の細胞膜輸送}

チアミンは自然界では遊離型以外に, チアミン 一リン酸やチアミンピロリン酸などのリン酸エス テルの形で存在する。一般に, 細胞膜は多くのリ ン酸ェステルに対して透過性がないとされている が，大腸菌ではチアミンリン酸エステルが，そ のままの形で取り込まれることが証明されてい る ${ }^{(21)}$. 酵母の場合は培地中のチアミンリン酸エス テルが細胞内にチアミンとして集積されるが，チ アミン輸送欠損株ではそのようなことは起こらな い. 実際に ${ }^{14} \mathrm{C}$ 標識チアミンより化学的に合成し たチアミンーリン酸とチアミンピロリン酸を用い て，酵母細胞と細胞壁を酵素的に除去したプロト プラストについて取り达みを調べると，生細胞で はチアミンの放射能の 細胞内蓄積が認められる が，プロトプラストでは放射能の取り込みが著し く低い(22). したがって，酵母はチアミンリン酸エ ステルをそのまま取り达まず，細胞膜の外でいっ たん酵素的に脱りン酸してから，チアミンとして 能動輸送するものと考兄られる.

チアミンの前駆体であるヒドロキシメチルピリ ミジンとヒドロキシェチルチアゾールも酵母細胞 内に速やかに取り込まれてチアミンの生合成に利 用されるが，ヒドロキシメチルピリミジンはその 化学構造が核酸のピリミジン塩基やビタミン $\mathrm{B}_{6}$ と類似することから，独自の輸送系が存在するか ぞらかに興味がもたれていた。しかし， ${ }^{3} \mathrm{H}$ 標識 ヒドロキシメチルピリミジンの取り达みが，チア ミン輸送欠損株では汪とんど起こらないことが見 いだされここの物質が主にチアミン輸送系を利用 


\begin{tabular}{|c|c|c|c|c|c|}
\hline 物質 & $\begin{array}{l}\text { 酵母細胞内へ } \\
\text { の取り込み }\end{array}$ & $\begin{array}{l}\text { 輸送反応 } \\
\text { (輸送系) }\end{array}$ & $\begin{array}{l}\text { 輸美直後 } \\
\text { の存在形 }\end{array}$ & $\begin{array}{l}\text { オーバーシニー } \\
\text { ト現象 }\end{array}$ & 輸送欠損変異株 \\
\hline チアミン & あり & $\begin{array}{l}\text { 態動輸送 } \\
\text { (チアシ輸送系) }\end{array}$ & 遊離型 & 認めない & $\begin{array}{l}\text { チアミンキャリアー } \\
\text { の活性低下 }\end{array}$ \\
\hline $\begin{array}{l}\text { ヒドロキシメチル } \\
\text { ピリミジン }\end{array}$ & あり & $\begin{array}{l}\text { 態動輸送 } \\
\text { (チアミ輸送系) }\end{array}$ & 遊離型 & 認める & 同上 \\
\hline $\begin{array}{l}\text { ヒドロキシエチル } \\
\text { チアゾール }\end{array}$ & あり & $\begin{array}{l}\text { 受動輸送 } \\
\text { (拡散) }\end{array}$ & $\begin{array}{l}\text { リン酸エ } \\
\text { ステル }\end{array}$ & 認めない & $\begin{array}{l}\text { ヒドロキシエチルチアゾ } \\
\text { ールキナーゼの活性低下 }\end{array}$ \\
\hline $\begin{array}{l}\text { チアミンリン酸 } \\
\text { エステル }\end{array}$ & $\begin{array}{l}\text { そのままの形 } \\
\text { では起こらな } \\
\text { い }\end{array}$ & $\begin{array}{l}\text { 細胞周辺腔でチアミ } \\
\text { ソ妿解されて } \\
\text { から能動輸罒系) } \\
\text { (チアミミ輸送系) }\end{array}$ & $\begin{array}{l}\text { チアミン } \\
\text { に同じ }\end{array}$ & $\begin{array}{l}\text { チアミンに } \\
\text { 同じ }\end{array}$ & チアミンに同じ \\
\hline
\end{tabular}

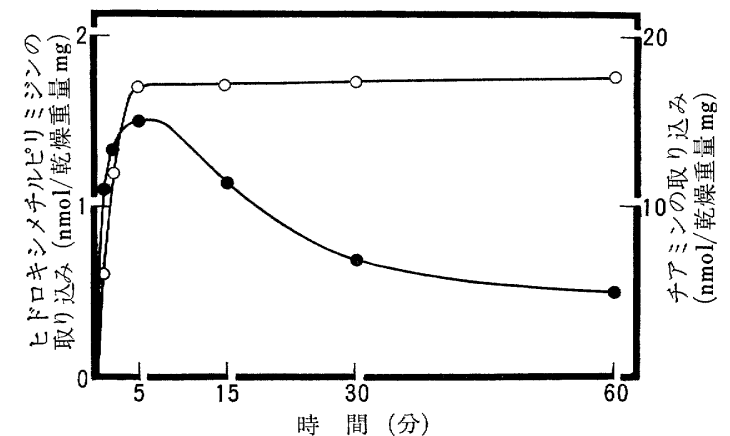

図 2 ロ酵母によるヒドロキシメチルピリミジンとチア ミンの取り込みの時間的経過

○：ヒドロキシメチルピリミジンの取り込み, ○:チアミンの 取り込み

して能動輸送されることが明らかになった ${ }^{(8)}$. こ のことは，前述の酵母のチアミン輸送系のピリミ ジン部に対する高い特異性からも理解される。た だ，チアミンの細胞膜輸送とは異なり，取り込ま れたヒドロキシメチルピリミジンのかなりの部分 が，短時間後に再び細胞外に排出されるために， ヒドロキシメチルピリミジンの取り込みには，図 2 に示すようなオーバーシュート現象が観察され る.

一方，ヒドロキシェチルチアゾールは酵母の細 胞膜を拡散，すなわち受動輸送により透過し， 細胞内でヒドロキシェチルチアゾールキナーゼ (EC 2.7.1.50) の作用を受けて速やかにリン酸化 され，ヒドロキシェチルチアゾールーリン酸とし て蓄積する ${ }^{(23)}$. また，本酵素を標的酵素として酵 母のチアミン生合成を阻害する 2-アミノヒドロ キシェチルチアゾールに対する耐性変異株には, 本酵素活性が汪とんど検出されず，同時にヒドロ キシェチルチアゾールの輸送能が注添完全に欠如 していることが見いだされている.このことは，
酵母によるヒドロキシェチルチアゾールの取り込 みに, 細胞内に和汀るリン酸化反応が重要な役割 を果たし，チアミンやヒドロキシメチルピリミジ ンの場合とは異なった輸送機構が存在することを 示している. 表 2 にチアミンとその関連化合物の 細胞膜輸送反応の主な性質を比較した.

\section{チアミンの細胞膜輸送と集積の調節}

酵母を培養する際に，培地中に $10 \mathrm{nM}$ 以上のチ アミンが含まれていると, その濃度に依存して培 養後の細胞のチアミン輸送能が低下し, $1 \mu \mathrm{M} に$ なるとほ注完に消失する ${ }^{(24)}$.この現象は外因性 のチアミンにより酵母の増殖時にもたらされる変 化で, 増殖後の細胞ではほとんど認められない. 李た, チアミンの存在下で増殖した酵母では, チ アミンの輸送能の低下とともに, 膜結合性チアミ ン結合タンパク質の活性が減少している(10).すな わち，酵母は，その増殖の間に培地中のチアミン を取り込み, 細胞内のチアミン（恐らくはチアミ ンピロリン酸) の濃度が一定值以上になると, 細 胞膜のチアミン結合タンパク質を含めチアミン輸 送系の合成を抑制して，チアミンの必要以上の集 積を制御しているものと考えられる.

ところで，酵母にはチアミン抑制性のチアミン 結合タンパク質が 細胞膜以外にも存在し, 筆者 ら ${ }^{(25)}$ は先に酵母のペリプラズム中にチアミンに 対して高い親和性を示して結合する分子量約 140 Kの糖タンパク質の合成が，培地のチアミンによ り抑制を受けることを電気泳動的に証明した。 そ こで, 本チアミン結合タンパク質を前述の膜結合 性チアミン結合タンパク質と区別するために, 可 溶性チアミン結合タンパク質と名づけたが(10), 


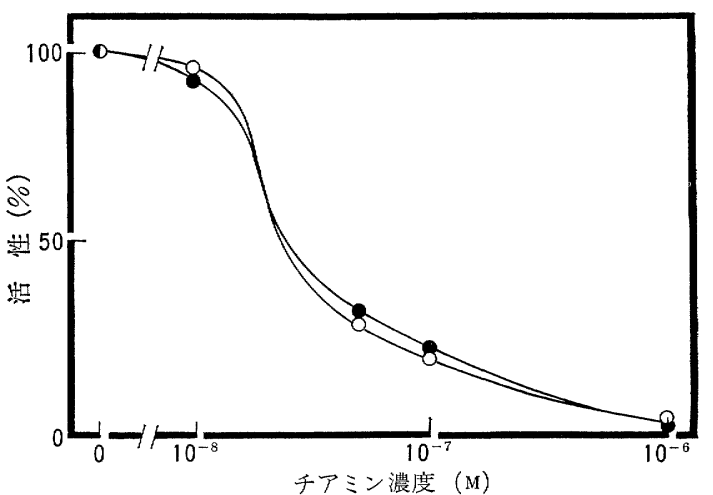

図 3・培地チアミン濃度による可溶性チアミン結合タン パク質と酸性ホスファターゼ活性の変動

○: 可溶性チアミン結合タンパク質, ○!酸性ホスファターゼ

その細胞周辺腔に初ける局在性から，当初はチア ミンの細胞膜輸送に何らかの機能を果たしている ことを予想した。 しかし，酵母のプロトプラスト には，可溶性チアミン結合タンパク質が含まれて いないにもかかわらず, チアミンを能動輸送し, その $K_{\mathrm{m}}$ 值や $V_{\max }$ 值も生細胞と比較して差異が 認められないことから，本結合タンパク質がチア ミンの細胞膜輸送に直接関与している可能性はき わめて少なく，その生理機能は別に存在すること が推定された ${ }^{(22)}$.

他方, 酵母の酸性ホスファターゼについて研究 していたスイスの Schweingruber ら ${ }^{(26)}$ は, 最近, リン酸非抑制性で従来構成型と考えられていたぺ リプラズムの酸性ホスファターゼ（構造遺伝子： $P H O$ 3) のメッセンジャーRNA の合成がチアミ ンにより抑制を受けることを見いだした。筆者ら は本酵素と可溶性チアミン結合タンパク質が，と もに分泌性の糖タンパク質で, その合成がチアミ ンにより抑制を受汀ることに注目し，両者の異同 について検討を加えたところ, 次のようないくつ かの実験事実から同一のタンパク質であることが 明らかになった ${ }^{(27)}$.

まず，図3は 1 倍体の Saccharomyces cerevisiae X 2180-1 A の可溶性チアミン結合タンパク 質と酸性ホスファターゼの活性が, 培地のチアミ ン濃度に依存して同じように低下することを示し ている，次に，酵母のペリプラズムより可溶性チ アミン結合タンパク質を精製すると, 酸性ホスフ
アターゼも同時に精製され，精製標品の電気泳動 でも両活性は分離することなく, 糖鎖を酵素的に 切断した後もまったく同一の挙動を示した. そこ で,さらに X 2180-1A を親株としてチアミン抑 制性酸性ホスファターゼが完全に欠損した変異株 を分離したところ, 本変異株のペリプラズムには チアミン結合活性がまったく認められず，その遺 伝学的解析から両活性の欠損が, 核性の単一遺伝 子 (PHO 3) に生じた劣性の変異であることもわ かり，両タンパク質が同一の遺伝子産物であるこ とが明確になった ${ }^{(28)}$.

このようなチアミン結合能をもつ酸性ホスファ ターゼにはどんな生理機能があるのであろうか.

一般に，酵母のペリプラズムに含まれる酸性ホス ファターゼの基質特異性は広く, 種々のリン酸エ ステルを細胞表層で加水分解して, 生じた無機り ン酸を細胞に与觉る作用をもつと考光られてい る(29). したがって，チアミン抑制性酸性ホスファ ターゼの機能を知る上で, その基質としてチアミ ンリン酸エステルが特別の意義をもつかどうかが 問題となる，そこで，本酵素の基質に対する親和 性を人工基質としてょく使用される $p^{-}$ニロ ェニルリン酸と, チアミン一リン酸和よびチアミ ンピロリン酸について，それらに対する酵素の $K_{\mathrm{m}}$ 值から比較してみると, 両チアミンリン酸エ ステルに対する親和性が人工基質のそれよりも約 1,000 倍高いことがわかった ${ }^{(30)}$. さらに, 本酵素 のチアミン結合活性の発現に必要なカルボキシル 残基を，1-エチル-3-(3-ジメチルアミノプロピ ル）カルボジイミドで修飾して失活させると，酵 素のチアミンリン酸エステルに対する親和性のみ が著しく低下し，その $K_{\mathrm{m}}$ 值が人工基質に対する のとほぼ等しい $\mathrm{mm}$ レベルにまで増加すること が明らかになった。

以上の実験結果は，チアミン抑制性酸性ホスフ アターゼが，従来考学られていたような非特異的 なホスファターゼではなく，チアミンリン酸エス テルに対して高い親和性をもって作用する酸性ホ スファターゼであることを示唆している，事実， 前述の本酵素の完全欠損株によるチアミンとチア ミンリン酸エステルの取り込みを親株と比較して 
調ベてみると, チアミンリン酸 エステルの放射能の取り込みの み親株に比べ, 変異株では著し く低下して和り，先の野生株の プロトプラストで得られたのと ほぼ同じような結果が得られ た ${ }^{(28)}$. したがって，外界のチア ミンリン酸エステルは, まず酵 母の細胞周辺腔でチアミン抑制 性酸性ホスファターゼにより加 水分解されてから，チアミンと して能動輸送されると考えるの が妥当であり，この際，酸性小 スファターゼとチアミン輸送系 がともに細胞内のチアミン（チ アミンピロリン酸) レベルに応

じて抑制されるので, チアミンとしての集積が二 段階にわたって調節を受けると考劣られる.

一方, ヒドロキシメチルピリミジンの酵母細胞 内への取り达みもチアミンにより抑制を受ける が, これは前述のように, 本前駆体がチアミン輸 送系を介して能動輸送されるので, チアミンの場 合と同じ機構で調節されることになる.また，こ れとは別にヒドロキシメチルピリミジンの細胞内 蓄積は，その排出系の作用によっても調節される が，この系はヒドロキシメチルピリミジンに特異 的でチアミンには作用しない. しかも, この排出 反応は土ネルギー依存性で, 酵母はいったん取り 込んだヒドロキシメチルピリミジンを積極的に汲 み出している.このような機構の存在意義に関連 して, ヒドロキシメチルピリミジンの酵母細胞内 に特沙る蓄積が代謝上有害であるかどうかは不明 であるが, 細菌や動物組識ではヒドロキシメチル ピリミジンがピリドキサールキナーゼ（EC 2.7.

1.35）の強い拮抗阻害物質であることが知られて いる(31,32).

これに対して, 酵母細胞内に集積されたチアミ ンは, 生理的な条件下では細胞外に排出されるよ らなことはない. チアミンの排出は酵母に 2,4ジニトロフェノールやカプロン酸のような $\mathrm{H}^{+}$伝 導体を作用させて, 細胞内外の $\mathrm{H}^{+}$の濃度勾配を
消失させた時のみ観察される ${ }^{(7)}$. しかし最近にな って, 酵母にもチアミンの排出系が存在し, 正常 な状態ではその作用の発現が抑制されていること を示唆する報告がみられている ${ }^{(33,34)}$.この研究は チアミンの含有量の高いビールを発酵生産する目 的で進められ, その結果, de novo 亿生合成された チアミンを細胞外に排出する突然变異株が酵母よ り数株分離された.これらの酵母の示すチアミン 排出能は劣性で, 核遺伝子の支配下にあるとされ ているが，チアミン集積能との関係や取り込まれ たチアミンの運命については明らかにされていな い.

ヒドロキシェチルチアゾールの取り込みの調節 は細胞膜段階ではなく，この物質を細胞内でリン 酸化して捕捉する役割を果たしているヒドロキシ エチルチアゾールキナーゼがチアミン（チアミン ピロリン酸）により抑制を受ける結果，リン酸エ ステルとしての細胞内蓄積が調節されることがわ かっている。

以上，述べてきた酵母に打けるチアミンとチア ミン関連化合物の細胞膜輸送とその調節の概略を 図 4 に示した。

\section{チアミンの集皘に伴う酵母の増殖と代謝の変化}

一般に，大部分の酵母はチアミンを生合成し， 
その増殖に チアミンを要求しないとされている が，培地にチアミンを添加すると，さらにその増 殖が促進される酵母も少なくない、したがって, 外部環境中に存在する既成のチアミンや，チアミ ンリン酸エステルをチアミンの形で速やかに細胞 内に集積する能動輸送系の存在は, それ自体生理 的な意義をもつと考光られる．酵母に対する外因 性のチアミンの生物学的作用としては, 古くから 嫌気性発酵を促進する効果のあることが知られ, この現象がチアミンの微量定量法に利用されたこ とがある(35)．実際にチアミンを取り込ませた酵母 細胞では，ブドウ糖の利用が増加するとともに解 糖系の酵素活性，殊にヘキソキナーゼ（EC 2.7.

1.1）の活性が上昇し，同時にエタノールの生成 量が増加することが観察されている(9). また，こ の際エタノールの生成が解糖系の活性とは別に, チアミン自体により調節を受けることも示唆され ているが，その機構は明らかではない。

一方, Saccharomyces carlsbergensis (S. uvarum) はビタミン $\mathrm{B}_{6}$ のバイオアッセイに最も広く用い られている酵母で, チアミンの存在下で好気的に 培養すると，その増殖にビタミン $\mathrm{B}_{6}$ を要求する ようになる性質が利用されている。このようなチ アミンによる酵母の 増殖阻害は他の Saccharomyces 酵母でも認められ, その阻害機構としては, 細胞内に蓄積した遊離型チアミンがビタミン $\mathrm{B}_{6}$ の生合成に関わるチアミンピロリン酸依存性の反 応を阻害することによると推定されている，チア ミンによりビタミン $\mathrm{B}_{6}$ の生合成が阻害される そ，その補酵素型であるピリドキサールリン酸の 関与する $\delta$-アミノレブリン酸合成酵素 (EC2.3. 1.37）の活性が低下してへムの合成が障害され， その結果, シトクロムが欠乏して呼吸阻害による 増殖抑制をもたらすことが実験的に示されてい る(9).したがって，前述のチアミンによる解糖の 促進は呼吸阻害に基づくパスッール効果の解除に よるものとも考觉られるが，いずれにしてもチア ミンの集積は好気条件下での酵母の増殖に対して 阻害的に作用することになる。また，これとは別 にチアミンを多量に集積した酵母のプロトプラス 卜は破壊され易く, 長時間の放置や浸透圧の変化
によりメチレン青染色性が著しく増加することか ら，酵母に悪影響を及洼しているとの報告 ${ }^{(36)}$ もあ り，チアミンの集積が酵母の増殖や代謝に対して 必ずしも有利であるとは思兑ないような現象も観 察されている。

最近, 淡水産の単細胞真核生物であるユーグレ ナ（ミドリムシ）が酵母と同じようにチアミンを 能動輸送し，遊離型チアミンを細胞内に多量蓄積 することが報告されているが(37)，植物では生合 成されたチアミンが主に遊離型で存在し，殊に種 子では遊離型チアミンに構造特異性のある結合タ ンパク質に結合して発芽まで保持されることが知 られている ${ }^{(38,39)}$. 酵母に限らず，このような補酵 素型でないチアミンを集積する生物に掞いて，蓄 積したチアミンが場合によっては他の代謝系を阻 害してでもチアミンピロリン酸を生成するために 多量に存在する必要性があるのか，あるい惟積 した遊離型チアミン自体に未知の機能が隠されて いるのか，これらは今後の研究で明らかにされる べき興味ある課題であると思われる.

\section{文献}

1）川崎近太郎，篠田純男，小野照代：ビタミン， 36， 535 (1967).

2) C. Eijkman, C. J. C. Van Hoogenhuijze \& T. J.G. Derks : J. Biol. Chem., 50, 311 (1922).

3) 高田亮平: 䁔造学雑誌, 11，563 (1933).

4) 大猚 了:農化誌, 10, 409 (1933).

5) Z. Suzuoki : J. Biochem., 42, 27 (1955).

6) 芦田 淳：農化誌, 18, 723 (1942).

7) A. Iwashıma, H. Nishino \& Y. Nose : Biochim Biophys. Acta, 330, 222 (1973).

8）岩島昭夫：ビタミン, 62, 471 (1988).

9) T. Kamihara \& I. Nakamura : Adv. Biochem. Eng. Biotech., 29, 36 (1984).

10) A. Iwashıma, H. Nishimura \& Y. Nose : Biochim. Biophys. Acta, 557, 217 (1979).

11) A. Iwashima \& Y. Nose : Biochim. Biophys. Acta, 399, 375 (1975).

12) 安楽泰宏: “新医科学大系 $2 \mathrm{~A}$ 細胞子細胞工学 I”, 中山書 店, 1985, p. 43

13) A. Iwashıma, Y. Wakabayashi \& Y. Nose : Biochim. Biophys. Acta, 413, 243 (1975).

14) A. Iwashıma, H. Nishimura \& K. Sempuku : Experientia, 36, 385 (1980).

15) A. Iwashima, Y. Wakabayash1 \& Y. Nose : J. Bacteriol., 131, 1013 (1977).

16) H. Nishimura, K. Nosaka, K. Sempuku \& A. Iwashima : Experientia, 42, 607 (1986).

17) K. Nosaka, H. Nishımura \& A. Iwashima : Biochim. 
Biophys. Acta, 858, 309 (1986).

18) K. Sempuku, H. Nishimura \& A. Iwashima : Biochim. Biophys. Acta, 645, 226 (1981).

19) K. Sempuku : Biochim. Biophys. Acta, 944, 177 (1988).

20) H. Nishimura, K. Sempuku, K. Nosaka, Y. Kawasaki \& A. Iwashima : FEBS Lett., 255, 154 (1989)

21) H. Nakayama \& R. Hayashi : J. Bacteriol., 109, 936 (1972).

22) H. Nishimura, K. Sempuku \& A. Iwashima : J. Bacteriol., 150, 960 (1982).

23) A. Iwashima, K. Nosaka, H. Nishimura \& Y. Kimura : J.Gen. Microbiol., 132, 1541 (1986).

24) A. Iwashima \& Y. Nose : J. Bacteriol., 128, 855 (1976).

25) A. Iwashima \& H. Nishimura: Biochim. Biophys. Acta, 577, 217 (1979).

26) M.E. Schweingruber, R. Fluri, K. Maundrell, A.-M. Schweingruber \& E. Dumermuth : J. Biol. Chem., 261, 15877 (1986).

27) K. Nosaka, H. Nishimura \& A. Iwashima : Biochim. Biophys. Acta, 967, 49 (1988).

28) K. Nosaka, Y. Kaneko, H. Nishimura \& A. Iwashima :
FEMS Microbiol. Lett., 60, 55 (1989).

29) M.E. Schweingruber : Adv. Prot. Phosphatases, 4, 77 (1987).

30) 野坂和人, 西村 洋, 岩島昭夫：ビタミン, 63, 187 (1989).

31) M. Tsubosaka \& K. Makino: J. Vitaminol., 15, 131 (1969).

32) T. Mizote \& H. Nakayama: Biochim. Biophys. Acta, 991, 109 (1989).

33) L. Silhankova: J. Inst. Brew., 91, 78 (1985).

34) L. Silhankova : J. Inst. Brew., 91, 238 (1985).

35) L. Atkin, A.S.Schultz \& C. N. Frey : J.Biol. Chem., 129, 471 (1939).

36）川崎近太郎, 篠田純男, 小野照代：ビタ ミン, 36, 530 (1967).

37) S. Shigeoka, T. Onishi, K. Maeda, Y. Nakano \& S. Kitaoka: Biochim. Biophys. Acta, 929, 247 (1987).

38) T.Mitsunaga, M. Shimizu \& A. Iwashima : J. Plant Physiol., 124, 177 (1986).

39) T.Mitsunaga, M.Shimizu \& A. Iwashima: J. Plant Physiol., 130, 279 (1987).

\title{
Intracellular Proteolysis
}

\author{
Mechanisms and Regulations \\ (細胞内蛋白質分解の機構と制御) \\ 勝沼信彦・小南英紀編 菊判 $/ 604$ 頁 $/ 15000$ 円(税込)
}

細胞内蛋白質分解は, 情報伝達, 受精, 細胞の增殖・分化その他多彩な生理現象, および 炎症や癌などの病態の素反応となる重要な生体反応である。これらに関与するプロテアー ゼとその制御系としてのインヒビターの蛋白・酵素化学の進展のみならず，近年遺伝子工 学・細胞工学的手法により, 蛋白質の構造と機能に関する情報と蛋白分解の機構の解析が 飛躍的に進展した。本書は，1988年に行われた国際会議をもとに国内外の第一線の研究者 による最新の知見を集録したものである。

〈主要テーマ〉 細胞内プロテアーゼの諸性質, 構造, 組織分布/プロテアーゼインヒビ夕 一/細胞内蛋白分解の機構と調節／細胞内プロテアーゼとインヒビターの生物学的および 病態学的意義.

好評既刊（定価は消費税拔きです）

\section{Calcium Signal and Cell Response}

八木康一・宮崎 保 編 9300 円

カルシウムシグナルと細胞応答に関する基礎 および臨床的アプローチ。
プロテアーゼ

一島英治 編著 5400 円 多彩な生理現象や炎症および癌などの病態の 生体反応の制御に与る醏素として最も注目さ れているプロテアーゼにまつわる諸問題を平 易に解説: 